Article

\title{
Have Housing Prices Gone with the Smelly Wind? Big Data Analysis on Landfill in Hong Kong
}

\author{
Rita Yi Man Li ${ }^{1, *}$ and Herru Ching $\mathrm{Yu} \mathrm{Li}^{2}$ \\ 1 Sustainable Real Estate Research Center/HKSYU Real Estate and Economics Research Lab/Department of \\ Economics and Finance, Hong Kong Shue Yan University, Hong Kong, China \\ 2 School of Computer Science, University of St Andrews, St Andrews KY169UH, UK; li.herru@gmail.com \\ * Correspondence: ymli@hksyu.edu; Tel.: +852-28048552
}

Received: 9 November 2017; Accepted: 24 January 2018; Published: 29 January 2018

\begin{abstract}
Unlike many other places around the globe, Hong Kong is a small city with a high population density. Some housing units are built near the sources of an externality, such as a landfill site. As the blocks of buildings are particularly tall, many are walled buildings that block the bad odor from the landfill. Thus, the wind blowing from a landfill site may not affect the entire building estate. Some buildings are more heavily affected than others, partly because walled buildings built near landfills are rare. Only a few studies currently examine the correlation between wind direction and the prices of walled buildings. In this paper, we aim to bridge this research gap by illustrating Hong Kong as a case study. Most previous research studies only examine a few factors affecting housing prices. Modern big data is characterized by its large volume of data, which includes various types of data that analysts would not necessarily sample, but instead merely observe to track what happens. Therefore, another innovative point of our paper, is that we adopt a big data approach to study this issue. In this aspect, this paper is the first of its kind. There are 53,071 observations in the 1999 to 2014 dataset, with 2,175,911 data entries. Our results reflect that when more municipal solid waste is sent to the South East New Territories Landfill, residents' complaints in Tseung Kwan O increase. However, entire property prices in the region also increase, which rejects our hypothesis. We speculate that as more people become aware of the housing estate due to complaints, with only a limited number of housing units affected by the smell, since the wind usually only blows in certain directions, the "advertisement effect" originating from complaints about the bad smell boosts the property prices of the unaffected units. That is, people become aware of the existence of the property, visit the site, and discover that only specific units facing one particular direction are affected. Then, they purchase units that are unaffected by the smelly wind, leading to an overall increase in property prices. The study's results may provide a new perspective on urban planning, and possible implications for other cities in view of the constant increase in population and expansion of landfill sites.
\end{abstract}

Keywords: landfill; property prices; externality; wind direction; advertisement

\section{Introduction}

The locations where housing is built in Hong Kong are somewhat unique in comparison to many other jurisdictions worldwide. One example of where housing estates have been built next to a landfill site is the South East New Territories Landfill in Tseung Kwan O. Problems such as bad odor emanating from the landfill have led to the site being relocated to Tai Chik Sha, with a total area of $100 \mathrm{ha}$, a maximum depth of $100 \mathrm{~m}$ for waste, and a maximum height of $135 \mathrm{mPD}$, which grows by 4500 tonnes/day [1], in spite of the introduction of landfill charges for generated waste [2]. The situation has further deteriorated following the completion of LOHAS Park. Despite many complaints being made against the major developer, CK Hutchison Holding Limited, the Chairperson, Li Ka Shing, has made positive comments relating to the landfill site and the air quality in Tseung Kwan O. 
In late 2014, a bill concerning the expansion of the landfill site was passed following investigations that revealed that the odor concentration in LOHAS Park was not as serious as the mass media reported. Besides, it was found that odor complaints varied between different levels of temperature and rainfall: the lower the mean ambient temperature and rainfall, the fewer odor complaints were received [3]. Furthermore, as high wind speed dilutes the odor, we speculate that the wind speed, rather than distance from the landfill, solely affects the property price. This paper will examine different variables, using big data analysis to understand the relationship between this negative externality arising from landfill sites and property prices.

\section{Literature Review}

\subsection{Factors Affecting Property Prices}

Previous research has suggested that transportation is one of the factors that has an impact on property prices [4]. However, in Taiwan, the Box-Cox hedonic pricing model suggests that accessibility to high speed rail has a minor impact on property prices [5]. Several Superfund sites in the United States have demonstrated the expected impact-Superfund sites negatively impact property values [6]. Findings have also shown that housing wealth effects are significant [7].

In addition to this, scholars have proven that other factors have an impact on property prices. For instance, a recent study conducted in New Zealand concluded that the real interest rate has an important and positive effect on housing prices [8], while property tax was seen as having a huge impact on housing prices in China. These results were produced through the use of Ordinary Least Square, with the study taking place in Shanghai [9]. A similar result was reported in Ohno and Shimizu [10], which showed that housing prices have increased with the level of income relating to the foreign capital inflow.

\subsection{Externality and Property Prices}

Real estate prices are affected by the quality of the environment [11]. Households care about local public goods, and vote with their feet to move to properties that best satisfy their preferences $[12,13]$. By measuring different variables, including the distance from the nearest highly hazardous plants and housing prices, among others, it was noted that different industrial areas had different reservations when it came to paying for avoidance, which were dependent on the distance from the facilities [14]. Cho et al. [15] used water quality to study how water deficiencies affect property prices. They demonstrated that in the presence of standard water quality regulation, the owner of the house should consider water quality, since water impairment will influence the property price.

In Naples, Paola, and Guidice, an increase of $1 \mathrm{~dB}$ in noise levels led to a depreciation of real estate values ranging from $0.30 \%$ to $0.33 \%$ [16]. Moreover, Brandt and Maennig [17] considered the effect of traffic noise generated from the road on housing prices using a nonlinear approach and a dataset that included price, property type, neighborhood, accessibility, noise, and other variables. They concluded that there was variability in the discounts, as well as a disproportionate increase in discounts. By using the same model, with price, neighborhood, structural environment accessibility, and wildfire data as variables, Stetler et al. [18] analyzed how wildfire risk affects property prices. This result is consistent with a study in Colorado, which showed that housing prices in northwest Montana could be adversely affected by the risk of wildfires.

Grislain-Letrémy and Katossky [14] investigated how hazardous industrial plants affect housing prices in France. By measuring different variables-including the distance from the nearest highly hazardous plants and housing prices, among others-it was noted that different industrial areas had varied reservations when it came to paying for the prevention, which were dependent on the distance away from the hazardous facilities. Their study used a hedonic housing price model with spatial autocorrelation to analyze the distance to the facility, stadium age, median household income, median household age, and other variables. It was found that the housing prices in the block groups closer 
to the facilities were higher; indeed, this resulted from estimates based on the 1990 and 2000 Census block groups, which are within five miles of every National Football League, National Basketball Association, Major League Baseball and National Hockey League facilities in the United States.

Jim and Chen [19] measured different elements, including the orientation of windows, greenspace views, property floor space, traffic noise expos and proximity distance to nature, e.g., lakes and forests. The result showed that properties with a greenspace view increased property housing prices by $7.1 \%$. Natural views, floor levels, and window orientation properties raised property prices by $13.2 \%, 9.2 \%$, and $1.0 \%$, respectively.

Dekkers and van der Straaten [20] studied the relationship between the noise generated from the airport and housing prices in Amsterdam. By using a spatially explicit hedonic pricing model, the research produced results that showed that a $1 \mathrm{~dB}$ noise reduction will lead to a marginal benefit of $€ 1459$ per house, and an overall benefit of $€ 574$ million. In addition, Brandt and Maennig [17] considered the effect of noise generated from the road on housing prices using a nonlinear approach with a dataset that included price, property type, neighborhood, accessibility, noise, and other variables. They concluded that there was variability in discounts, as well as a disproportionate increase in discounts. By using the same model and examining factors such as neighborhood, structure environment accessibility, and wildfire data, Stetler et al. [18] analyzed how the risk of wildfire affects property prices. The result is consistent with the aforementioned study in Colorado, and showed that housing prices in northwest Montana could be adversely affected by the risk of wildfires.

Phillips et al. [21]'s Geographic Information System research found that a modern operational incinerator had a significant negative effect on the prices of property within a 5-km radius. Indeed, the greater the distance away from those facilities, the fewer the adverse effects. Various studies in this regard have focused on the actual impact that a landfill site has on neighborhoods [22-24]. Some studies indicated that the existence of a landfill site reduced housing prices $[25,26]$. In Toronto, Canada, it was shown that closer proximity to the landfill site had a stronger negative impact on property values with smaller landfill sites [27]. According to other studies, environmental quality and housing prices remained constant, even if the hazardous waste was removed [28], or the landfill site was shut down [29].

In conclusion, the above literature review provides evidence that landfill sites directly affect property prices. Nevertheless, only a few studies exist that have examined the correlation between wind direction and house prices.

\section{Hypotheses}

According to the literature discussed above, we assume that the factors that adversely or positively affected housing prices in the previous research also hold true. For instance, the further the distance that housing units are away from a landfill, the less affected they are compared with those closer to a landfill, and so on.

Specifically, we aim to study the following three hypotheses:

- H1: The flats that face the landfill directly and are hit by the wind from a certain direction have a negative relationship with housing prices, but this is not so for other flats that are not facing the landfill and are not being hit by wind from a certain direction.

- H2: The volume of rainfall in Tseung Kwan O has a negative relationship with housing prices in Tseung Kwan O.

- H3: The environmental complaints (received by the Environmental Protection Department) relative to the South East New Territories Landfill negatively affect Tseung Kwan O's housing prices.

While past studies only included a few variables, other previous research showed that there are many variables that may affect housing prices in the real world. As such, we will employ big data analysis to test our hypotheses in the following criteria. 


\section{Research Method}

\subsection{Big Data Analysis}

Data can be 'big' in various ways. Data can be big due to the challenges that may arise in an experimental setting [30]. Big data can also be defined as a large volume of unstructured and structured data from various sources [30]. Academically speaking, the advent of big data has enabled novel research across a wide range of topics. This has also led to the development of various large-data statistical methods [31]. Unlike traditional studies relating to housing prices, which had to consider which variables should be included in the research, "big data doesn't sample; it just observes and tracks what happens" [32]. Thus, big data often includes data with sizes beyond the ability of traditional software to process within an acceptable time [33]. Due to recent technological advances, the ease of publishing new data, and the requirement of higher transparency among most of the governments around the world, big data analysis is becoming more prominent in modern research study.

Several investigators have used big data for analysis in different fields of research as a benchmark to analyze certain projects. A study of Hong Kong landfill waste generated a rate by collecting data and grouping the projects into different categories and different waste types. The result illustrated that demolition was the most wasteful type of work, generating inert and non-inert construction waste. Similarly, it was concluded that civil and foundation works also generated large amounts of inert waste, but less non-inert waste. Hromada (2015) applied big data in the Czech Republic, and demonstrated that there was a steady long-term decrease in real estate market prices after the second quarter in 2008, while a significant negative trend was observed within the same period.

\subsection{Hedonic Pricing Model}

Li suggested that the hedonic model $(P=f 1, f 2, f 3, \ldots, f n)$ is often used to study the impact of a number of factors that affect housing prices [34]. Lavee and Bahar elaborated on the hedonic model by providing the following equation: $\mathrm{Pi}=\mathrm{f}(\mathrm{d}, \mathrm{s} 1, \mathrm{~s} 2, \ldots \mathrm{sn} ; \mathrm{n} 1, \mathrm{n} 2, \ldots, \mathrm{nm})$, where pi is the transaction price of an apartment, $\mathrm{f}$ is the function that studies the relationship between housing prices and the distance of the housing from the environmental hazard (d), $\mathrm{s}$ is the characteristics of the housing structure, and $\mathrm{n}$ is the characteristics of the housing's neighborhood. The model assumes that the housing market is in equilibrium, i.e., all of the individuals are profit maximizers [35]. It is one of the most popular tools used in environmental disamenities valuation. Previous research has examined the impact of land contamination [36] and negative environmental externalities on housing prices [34].

The hedonic pricing model has been adopted to study negative externalities. For example, $\mathrm{Li}$ and Brown applied the hedonic pricing model, and found that the effect of noise pollution reduced housing prices by an average of US $\$ 460$ for each doubling of the perceived level of noise [37]. In one recent study, it was found that the negative impact of incinerators on house prices varied from approximately $0.4 \%$ to $1.3 \%$. Nevertheless, some incinerators increased the housing prices within a specified distance, under specific circumstances [38].

\subsection{Heteroscedasticity and Autocorrelation Consistent (HAC)}

Heteroscedasticity and autocorrelation consistent (HAC) covariance matrix estimation is a calculation of variance matrices to overcome the conditional heteroscedasticity and the serial correlation problem that may exist in hedonic regression. The covariance matrix is usually denoted by the following:

$$
\Psi=\operatorname{VAR}[\hat{\delta}]=\left(y^{T} y\right)^{-1} y^{T} \Omega y\left(y^{T} y\right)^{-1}=\left(\frac{1}{n} y^{T} y\right)^{-1} \frac{1}{n} \Phi\left(\frac{1}{n} y^{T} y\right)^{-1}
$$

where $\Phi=\mathrm{n}^{-1} \mathrm{y}^{\mathrm{T}} \Omega \mathrm{y}$ is the scores covariance matrix or estimating functions $\mathrm{V}_{\mathrm{i}}(\delta)=\mathrm{y}_{\mathrm{i}}\left(\mathrm{x}_{\mathrm{i}}-\mathrm{y}_{\mathrm{i}}^{\mathrm{T}} \delta\right)$. The parameter estimates $\hat{v}_{i}=v_{i}(\hat{\delta})$ are evaluated in the estimating function, and have a sum equal 
to zero [39]. Al-Zoubi and Maghyereh [40] indicated that stock prices had a close relationship with the HAC, as there was strong evidence to show that mean reversion in stock prices was documented for equally-weighted portfolios. Kim and Sun [41] performed a study to investigate the spatial HAC. They found that the optimal bandwidth parameter was not feasible in practice, and suggested a data-dependent bandwidth parameter estimator using a parametric plug-in method.

\subsection{Expectation Maximization}

Dempster et al. [42] suggested that expectation maximization could be used as an iterative optimization procedure for computing maximum likelihood (ML) or a maximum a posteriori parameter estimate of the incomplete data problem. Expectation maximization holds that the iteration between the algorithms includes an expectation step followed by a maximization step. It is an associated theory that is simple and general. Miljkovic and Barabanov [43] indicated that every iteration of the expectation maximization algorithm includes two steps, which are usually termed the E-step and M-step.

For the E-step, we attempt to restore the value of incomplete observations using the fixed parameters of the model. In contrast, for the M-step, the parameters of the model are recomputed based on the new values of observations found during the E-step. Do and Batzoglou [44] pointed out that expectation maximization provides a simple and efficient way to learn the parameters of a model. By means of weighted training examples, rather than selecting the single best completion, the expectation maximization algorithm accounts for the model's confidence level in each data segment. It is widely used in engineering and statistical literature as an iterative optimization procedure for computing maximum likelihood or for maximum a posteriori parameter estimates of the incomplete data problem.

Expectation maximization has many applications in reality; for example, it can be applied to find the extremum of the objective function that corresponds to the transmitter location, which is used extensively in civilian and military applications [45]. Research by Dadashkarimi et al. [46] determined that expectation maximization algorithms could be applied for query translation. Fort and Mungan [47] forwarded the belief that one way to uncover the structure underlying complex networks is to utilize information theoretical statistical inference methods, such as the expectation maximization algorithm.

\subsection{Cubic Spline Interpolation}

A cubic spline is a popular tool for model interpolation, and one that we have also utilized for such purposes in this paper. A spline is also commonly used for drafting, which can aid people in drawing smooth curves, and make it possible to connect the points, even when there are wide spaces between them [48]. Gao, Zhang, and Cao [48] explained the formula of cubic spline interpolation in their paper; they assumed that there are $N+1$ points, and that $\left\{\left(x_{i}, y_{i}\right)\right\}_{i=0}^{N}$, where $a=x_{0}, x_{1}, \ldots, x_{n}=b$. A function is termed a cubic spline $S(x)$ where there is an exit of $N$ cubic polynomials, and they satisfy the following properties:

$$
\begin{aligned}
& \mathrm{S}(\mathrm{x}) \text { is a cubic polynomial on }\left[\mathrm{x}_{\mathrm{i}-1}, \mathrm{x}_{\mathrm{i}}\right](\mathrm{i}=1,2, \ldots, \mathrm{n}) \\
& \qquad \begin{array}{c}
\mathrm{S}\left(\mathrm{x}_{\mathrm{i}}^{-}\right)=\mathrm{S}\left(\mathrm{x}_{\mathrm{i}}^{+}\right)(\mathrm{i}=1,2, \ldots, \mathrm{n}-1) \\
\mathrm{S}^{\prime}\left(\mathrm{x}_{\mathrm{i}}^{-}\right)=\mathrm{S}^{\prime}\left(\mathrm{x}_{\mathrm{i}}^{+}\right)(\mathrm{i}=1,2, \ldots, \mathrm{n}-1) \\
\mathrm{S}^{\prime \prime}\left(\mathrm{x}_{\mathrm{i}}^{-}\right)=\mathrm{S}^{\prime \prime}\left(\mathrm{x}_{\mathrm{i}}^{+}\right)(\mathrm{i}=1,2, \ldots, \mathrm{n}-1) \\
\mathrm{S}\left(\mathrm{x}_{\mathrm{i}}\right)=\mathrm{y}_{\mathrm{i}}(\mathrm{i}=0,1, \ldots, \mathrm{n})
\end{array}
\end{aligned}
$$

The formula leaves us with two additional degrees of freedom, and the choice of these two extra conditions determines the type of the cubic spline obtained. Cubic spline interpolation is widely used in computing areas. Kim and Kvasov [49] addressed a new type of cubic spline in their paper, termed the weighted B-spline. This is a useful and efficient tool in computer-aided design when there is a need to control tension on intervals connecting interpolation points. Abbas et al. [50] suggested that in 
computing an area, the bi-cubic spline interpolation could be used to conserve the inherited shape feature (positivity) of three-dimensional (3D) data.

\section{Description of Data and Variable}

\subsection{Study Sample: Tseung Kwan $O$}

Tseung Kwan O, located in the southern part of Sai Kung, is the seventh new town in Hong Kong, according to the Territorial Development Strategy Review. The development of Tseung Kwan O was permitted by the Executive Council in 1982. Since 1988, Tseung Kwan O has been rapidly expanding, and the first public housing estates were built and made available for habitation in Po Lam and Tsui Lam. Strategic growth in the South East New Territories Landfill will be confined to Tseung Kwan O. The government also included industrial and port developments in its future development plans, due to a large capacity for external roads and a railway link to the city's central area and financial hub.

Aside from planning zoned areas, the development proposal also incorporates a sub-region for green conservation and recreation, as well as housing estates; eventually, it will become a hinterland in Tseung Kwan O. In addition, the initiative includes further strategic planning of all-round development to prepare for future expansion, given the 520,000 residents who are estimated to be living in Tseung Kwan O. Tseung Kwan O would change from its 1960s status as a fishing village with specialized factories for shipbuilding into a community of 450,000 people, and 1738 hectares of development area (Pland.gov.hk, 2015).

The transportation to the new town can be divided into railway and road transport. Indeed, August 2002 saw the commissioning of the Tseung Kwan O Tunnel, Clean Water Bay Road, Po Lam Road, and the Mass Transit Railway (MTR) extension, which are five newly proposed stations on the Tseung Kwan O line. There are also new road links (Lam Tin Tunnel and Cross Bay Link) currently under development (Pland.gov.hk, 2015).

The project aims to construct a HAC regression model that relates to negative externality, property prices, and other economic factors. Tseung Kwan O residents constantly complain about odor problems from the nearby South East New Territories Landfill, which has largely not been analyzed to date. This means that there is still much to discover. We consider all of the Tseung Kwan O housing transactions near the South East New Territories Landfill until 2014. This is mainly because other related data, including macroeconomic data and climatic information, are not readily available. Given this availability constraint, there are 10 housing estates included in the study sample: LOHAS Park, Residence Oasis, Ocean Shores, The Wings, Park Central, The Grandiose, Tseung Kwan O Plaza, Oscar by the Sea, La Cite Noble, and Bauhinia Garden. The background of the properties will be explained below.

\subsection{Sample Estates and Introduction to Variables Used}

The following sample estates are included in this study due to their relative closeness to the South East New Territories Landfill and private housing estates: Park Central, Tseung Kwan O Plaza, Oscar by the Sea, La Cite Noble, and Bauhinia Garden (Appendix A Table A1). Complaints from the residents about the odor emanating from the landfill are the primary reason for including these estates in the sample (www1.centadata.com, 2015). Table 1 summarizes information related to the sample estates. 
Table 1. Basic information from the dataset. MTR: Mass Transit Railway, US: United States, UK: United Kingdom; HK: Hong Kong; HSI: Hang Seng Index; HIBOR: Hong Kong Interbank Offered Rate.

\begin{tabular}{|c|c|c|c|c|c|}
\hline Variables & Mean & Median & Standard Deviation & Minimum & Maximum \\
\hline Floor (square feet) & 29.31 & 29.00 & 16.37 & 1.00 & 76.00 \\
\hline Area Saleable & 570.46 & 518.00 & 141.21 & 68.00 & 1988.00 \\
\hline Area Gross & 758.93 & 693.00 & 186.56 & 502.00 & 2276.00 \\
\hline Price (million) & 318.49 & 273.00 & 172.51 & 0.00 & 7780.00 \\
\hline Trans. Date & $38,887.84$ & $38,681.00$ & 1469.56 & $36,162.00$ & $42,004.00$ \\
\hline Housing Unit & 349.28 & 376.00 & 77.85 & 128.00 & 506.00 \\
\hline Car Park & 764.12 & 900.00 & 340.81 & 154.00 & 1250.00 \\
\hline Housing Age & 11.63 & 13.00 & 3.43 & 3.00 & 16.00 \\
\hline Distance From Landfill & 3.48 & 3.72 & 0.71 & 1.77 & 4.29 \\
\hline Distance from Wan Po Road & 0.71 & 0.52 & 0.53 & 0.04 & 1.60 \\
\hline Distance to MTR & 0.23 & 0.21 & 0.12 & 0.04 & 0.61 \\
\hline Volume Heng Seng Index (million) & 1050 & 588 & 993 & 3.7 & 9,800 \\
\hline Adjusted Close Heng Seng Index & $15,499.89$ & $15,654.13$ & 7000.93 & 0.00 & $31,638.22$ \\
\hline Mean Degree Celcius & 21.99 & 22.10 & 4.92 & 7.70 & 31.70 \\
\hline Total Rainfall (mm) & 5.73 & 0.00 & 18.56 & 0.00 & 313.00 \\
\hline Prevailing Wind Direction (degrees) & 118.28 & 70.00 & 103.90 & 10.00 & 360.00 \\
\hline Mean Wind Speed $(\mathrm{km} / \mathrm{h})$ & 6.62 & 6.40 & 2.12 & 1.00 & 25.40 \\
\hline Population & 6900.15 & 6837.80 & 160.49 & 6637.60 & 7266.50 \\
\hline The United States Real Interest Rate & 7.02 & 7.00 & 3.68 & 0.73 & 14.26 \\
\hline The United States Business Cycle & $(13.74)$ & $(35.59)$ & 58.94 & $(86.40)$ & 110.06 \\
\hline Hong Kong Business Cycle & $(1309.72)$ & $(4188.54)$ & $20,425.78$ & $(39,575.70)$ & $58,027.17$ \\
\hline Complaints & 435.70 & 106.00 & 617.63 & 0.00 & 2466.00 \\
\hline Hong Kong Real Interest Rate & 3.27 & 2.54 & 1.71 & 1.16 & 6.88 \\
\hline New Housing Completion & $18,157.45$ & $17,320.00$ & $8,410.48$ & 7160.00 & $35,320.00$ \\
\hline Private Housing Vacancy & $52,555.82$ & $54,950.00$ & $10,866.77$ & $36,370.00$ & $68,780.00$ \\
\hline Public Housing Supply & 1097.07 & 1096.00 & 37.92 & 969.00 & 1176.00 \\
\hline Private housing Supply & 1311.09 & 1312.00 & 105.34 & 1072.00 & 1470.00 \\
\hline Overall Housing Supply & 2408.37 & 2408.00 & 141.13 & 2040.00 & 2645.00 \\
\hline Municipal Solid Waste & 2386.06 & 2405.00 & 221.69 & 1713.00 & 2687.00 \\
\hline New Loan Drawn & 9148.01 & 8639.00 & 3219.42 & $3,637.00$ & $17,207.00$ \\
\hline Unemployment Rate (\%) & 2.46 & 2.30 & 0.64 & 1.20 & 4.30 \\
\hline Discount Window Base Rate & 3.17 & 2.75 & 2.35 & 0.50 & 8.00 \\
\hline Overnight Hong Kong Interbank Offered Rate & 1.81 & 1.44 & 2.03 & 0.00 & 7.06 \\
\hline Best Lending Rate & 5.86 & 5.00 & 1.34 & 5.00 & 9.50 \\
\hline Consumer Price Index & 96.79 & 95.50 & 7.40 & 88.30 & 123.40 \\
\hline Money Supply (M2) & $5,312,683.00$ & $4,320,747.00$ & $1,911,574.00$ & $3,114,847.00$ & $11,038,198.00$ \\
\hline New Loan Drawn Amount & $17,450.47$ & $13,304.00$ & 9183.96 & 4159.00 & $43,504.00$ \\
\hline
\end{tabular}

\section{Results}

In this research, seven models utilize property prices as the dependent variable, while the remaining two models utilize price $/ \mathrm{ft}^{2}$ (ppsf) in the gross and saleable area, respectively. It is worth mentioning that one of the models utilizes the transactions between 2004-2014 due to the unavailability of data. There are 53,071 observations in the 1999 to 2014 dataset, with 2,175,911 data entries. For the 2004 to 2014 dataset, there are 34,649 observations, with 1,420,609 data entries. All of the values taken have a significance level of $1 \%$. All of the property prices mentioned below are in Hong Kong Dollars (HKD). Tables 2 and 3 show the HAC regression results, the expected an dactual sign for all the variables in the models. Appendix A Tables A3 and A4 record the correlation matrix of the variables and the adjusted R-squared summary for the HAC models.

\subsection{Factors with Positive Impact as Expected}

It is hypothesized that wind speed in Tseung Kwan $\mathrm{O}$ has a positive relationship with house prices because wind eliminates the bad odor. All of the results are significant at the $1 \%$ level. As the speed increases by one unit, house prices increase. Theoretically speaking, higher floors offer a better view and cleaner air, which leads to higher housing prices in Hong Kong. Our estimation does not reject the hypothesis. An increase in the saleable area leads to an increase in housing prices from approximately $\$ 683,829$ to $\$ 783,199$. It is also hypothesized that new loan transactions have a positive relationship with housing prices because more transactions lead to more demand. The results are significant at the $1 \%$ level. When new loan transactions increase by one unit, the house prices increase. This estimation does not reject our hypothesis. 
A one-unit $\left(\mathrm{ft}^{2}\right)$ increase in gross area will lead to an increase in housing prices from approximately $\$ 527,871$ to $\$ 537,558$. Furthermore, a one-unit increase of saleable area leads to an increase in housing prices from approximately $\$ 683,829$ to $\$ 783,199$. A $1 \%$ increase in Consumer Price Index leads to a $\$ 3,559,715$ increase in house prices and increases the property price per square feet (ppsf) by $\$ 119.3387$. This is because inflation measured by CPI decreases purchasing power, given the low bank interest rates. Thus, the demand for real estate surges, in turn leading to higher housing prices. It is assumed that Money Supply (M2) has a positive relationship with housing prices. As M2 increases by one unit, housing prices will rise by 0.0618 . This shows that there is an inflow of hot money into the Tseng Kwan O market.

When there is a one-unit increase in the resident population, housing prices will increase by between 98.284 and 1002.374. The estimation does not reject our hypothesis. The South East New Territories Landfill generates putrid odors. A one-unit increase in distance causes housing prices to rise from $\$ 13,252.70$ to $\$ 66,554$.53. Many garbage trucks pass by it every day, resulting in a bad odor. A one-unit increase in the distance from the Wan Po Road raises property prices from $\$ 40,142.72$ to $\$ 108,043.20$; ppsf increases from $\$ 504,376$ to $\$ 1,623,392$. It is hypothesized that distance from the landfill has a positive relationship with housing prices due to the bad odor emanated from the landfill.

\subsection{Factors with Unexpected Positive Correlations to Property Price}

It is hypothesized that municipal solid waste (MSW) has a negative relationship with housing prices. Firstly, there are social costs imposed on the housing units nearby. Secondly, most residents have complained about the bad odor emanated from the landfill. However, when the waste increases by one unit, the housing prices increase from $\$ 32,514$ to $\$ 56,067$. As the South East New Territories Landfill is well developed to reduce the odor concentration, even as waste increases, the housing prices do not drop. The interaction term of municipal solid waste, multiplied by the housing units affected by wind, refers to units that can smell the garbage odor from the landfill when the winds blowing exhibit 99\% significant negative; meaning that those units with bad odor winds blowing toward them are adversely affected.

Many of the building structures in Tseung Kwan O are very tall, with some over 50 storeys high, which in turn acts as a barrier to block the bad odor. Thus, not all of the buildings next to the landfill are adversely affected by the bad odor; the majority cannot smell the bad odor wind, even though they are located near the landfill. However, the frequent negative reports from the district encourage potential home buyers who wish to purchase a house at an affordable price to conduct site visits. To purchase and own a home is one of the most important dreams among Hong Kongers, yet even a young judge just over 30 years old can only afford to purchase a house without a bedroom, let alone other young families. Upon personally visiting the site, potential buyers learn the truth that not all of the houses are adversely affected by the bad odor, and they are hence willing to pay a higher purchase price.

It is hypothesized that the temperature in Tseung Kwan O negatively affects housing prices. A study conducted by the Hong Kong Polytechnic University showed that when the temperature was at 25 Degree Celsius, it was easier to smell garbage odors emanating from the South East New Territories Landfill. However, when the temperature rose by one unit, the housing prices increased by between 324.319 and 925.659 in the HAC model.

\subsection{Factors that Negatively Affect Property Prices as Expected}

When there is a $1 \%$ increase in the best lending rate, housing prices drop by between $\$ 18,237.26$ and $\$ 28,681.17$ in the HAC model. Mortgage repayments lead to an increase in the discount window base rate. A $1 \%$ increase in the rate leads to a $\$ 14,314.69$ drop in housing prices, as well as an average selling price drop of $\$ 585,335.50$. As the United States real interest rate increases, the interest rates in Hong Kong must follow suit, thus increasing mortgage repayments. When there is a $1 \%$ increase in the United States real interest rate, the property prices drop from $\$ 9302.845$ to $\$ 4957.274$, and ppsf in gross and saleable area decreases by $\$ 4.955206$ and $\$ 14.01284$, respectively. When there is a $1 \%$ increase in 
overnight Hong Kong Interbank Offered Rate (HIBOR), the house prices drop to around 3455.529, and the price per $\mathrm{ft}^{2}$ will drop to $\$ 187.3119$.

When there is a one-unit increase in the number of private housing vacancies, the property prices will drop by around 2.314 and 5.835. New housing completion (NHC) has a negative relationship with housing prices, because new houses mean more supply to meet demand, thus reducing the housing prices. The result is $99 \%$ significant, meaning that if NHC increases by one unit, housing prices decrease by 1.861 . This estimation does not reject our hypothesis. It is believed that the number of housing units has a negative relationship with housing prices, as more housing units increase the residential density.

In Table 2, all of the results exhibit a 99\% significance. As housing units increase by one unit, housing prices drop by approximately 140.926 to 524.525 , and the price of saleable feet per square will drop to 2.037006 in the HAC model. As the distance to the Mass Transit Railway station increases by one unit, the house prices will decrease by $\$ 63,516.17$ to $\$ 122,943.40$. When there is a one-unit increase in private housing, housing prices will drop from $\$ 950,728$ to $\$ 845,204$. Older buildings require more maintenance. Thus, as housing age increases by one unit, the property price drops from $\$ 22,862.98$ to $\$ 22,559.81$. An increase in the unemployment rate diminishes the wealth effect. Hence, a one-unit increase in the unemployment rate will decrease housing prices by $\$ 16,575.74$ to $\$ 19,178.19$ and decrease ppsf in saleable area by $\$ 919.2722$. It is hypothesized that unemployment rates have a negative relationship with housing prices. This is due to when the unemployment rate increases, housing demand decreases as the wealth effect diminishes. 
Table 2. Results of the heteroscedasticity and autocorrelation consistent (HAC) regressions. MTR: Mass Transit Railway.

\begin{tabular}{|c|c|c|c|c|c|c|c|c|c|}
\hline Variables & Model 1 & Model 2 & Model 3 & Model 4 & Model 5 & Model 6 & Model 7 & Model 8 & Model 9 \\
\hline Dependent Variables & Property Price & Property Price & Property Price & Property Price & Property Price & PRICEFT2GROSS & PRICEFT2SALEABLE & Property Price & Property Price \\
\hline $\begin{array}{l}\text { Data Range } \\
\text { Dang }\end{array}$ & $1999-2014$ & 1999-2014 & 1999-2014 & 1999-2014 & $1999-2014$ & 1999-2014 & 1999-2014 & 2004-2014 & $1999-2014$ \\
\hline $\begin{array}{l}\text { Independent Variables } \\
\text { AdjustedClose Heng Seng Index }\end{array}$ & & & & & & & & & \\
\hline $\begin{array}{l}\text { AdjustedClose Heng Seng Index } \\
\text { Gross Area }\end{array}$ & -0.0002 ** & $-0.0002^{* *}$ & 0.5376 & $0.5279 * * *$ & & & & & \\
\hline Saleable Area & $0.6838 * * *$ & 0.6986 ** & $0.50 \% 0$ & & 0.6745 ** & & & 0.7832 & \\
\hline Best Lending Rate & $-28.6812 * *$ & & & $-24.2730 * *$ & $-20.2410 * *$ & & & & $-18.2372 * * *$ \\
\hline Constant & $-4080.9650 * *$ & $992.6282 * *$ & $-3919.0110 * * *$ & $-4782.39 *$ & $606.9389 * *$ & $-7197.715 *$ & $12,336.91^{* * *}$ & 13.0925 & $-427,268^{* * *}$ \\
\hline Car Park & & & $-0.059569 * * *$ & & $-0.09592 * * *$ & & $-1.3897 * * *$ & $-0.08457 * * *$ & $-0.0686 * * *$ \\
\hline Consumer Price Index & $3.5598 * * *$ & & & & & $119.3387^{* * *}$ & & $5.8792 * * *$ & $5.6504^{* * *}$ \\
\hline Discount Window Base Rate & & & $-14.31469 * * *$ & & & & $-585,335 * * *$ & & \\
\hline Distance From Landfill & $59.16004 * * *$ & $13.25271^{* * *}$ & $66.5545 * * *$ & $65.6498^{* * *}$ & & & & & $37.6963 * * *$ \\
\hline Distance from Wan Po Road & $45.55387^{* * *}$ & $49.56781^{* * *}$ & $76.00587 * * *$ & $40.14272 * * *$ & $98.7769 * * *$ & $504.0376^{* * *}$ & $1623.392 * * *$ & $87.7634 * * *$ & $108.0432 * * *$ \\
\hline Distance to Mass Transit Railway & & -63.5161 *** & & & $-122.9434 * * *$ & & & & \\
\hline Floor & $0.9828 * * *$ & & $0.9570 * * *$ & $0.9774^{* * *}$ & & $13.6541^{* * *}$ & & $0.8007 * * *$ & $1.1569 * * *$ \\
\hline Hong Kong Business Cycle & $0.000195 * * *$ & $0.0002 * * *$ & & $0.00018^{* * *}$ & $0.000265 * * *$ & & $0.006502 * * *$ & $0.000216 * * *$ & $0.0001^{* * *}$ \\
\hline Hong Kong Real Interest Rate & & $-19.6209^{* * *}$ & & & & & & & \\
\hline Housing Age & $-12.3029 * * *$ & $-14.5603^{* * *}$ & $-13.2590 * * *$ & $-13.0793 * * *$ & $-2.2863 * * *$ & & & $-6.7832 * * *$ & $-22.5598^{* * *}$ \\
\hline Housing Unit & $-0.2023 * * *$ & $-0.1409^{* * *}$ & $-0.2943^{* * * *}$ & $-0.1971^{* * *}$ & $-0.2180^{* * *}$ & & $-2.0370^{* * *}$ & $-0.17015^{* * *}$ & $-0.5245^{* * *}$ \\
\hline Money Supply (M2) & & $0.0000618^{* * *}$ & & & & & & & \\
\hline Mean Degree Celcius & & $0.3900 * * *$ & $0.3243^{* * *}$ & & & & & $0.925659 * * *$ & \\
\hline Mean Wind Speed Km/h & & & & & $2.5848 * * *$ & & $30.0798 * * *$ & $0.5941 * * *$ & \\
\hline MSW & $0.03251^{* * *}$ & $0.05607 * * *$ & & & & & & & \\
\hline New Housing Completion & & $-0.0019^{* * *}$ & & & & & & & \\
\hline New Loan Drawn Amount & & $0.000991 * * *$ & & $0.000457 * * *$ & & & & $0.000504 * * *$ & \\
\hline New Loan Drawn & $0.000507^{* * *}$ & & & & & $0.01130 * * *$ & $0.0053 *$ & & \\
\hline Overall Housing Supply & & & $-0.7326 * * *$ & $-0.8564 * * *$ & & & & $-0.2642 * * *$ & \\
\hline Overnight Hong Kong Interbank Offered Rate & & $-3.4555 * * *$ & & & & $-187,311 * * *$ & & & \\
\hline $\begin{array}{l}\text { Private Housing Vacancy } \\
\text { Pand }\end{array}$ & & & & & $-0.00583 * * *$ & & & & $-0.0023 * * *$ \\
\hline Private Housing Supply & $-0.5177 * * *$ & $-0.26852 * * *$ & & & & & & & \\
\hline Public Housing Supply & $-0.9507 * * *$ & $-0.8452^{* * *}$ & & & & & & & \\
\hline Resident Population & $0.7933 * * *$ & & $0.8239 * * *$ & $1.0024^{* * *}$ & & & & & $0.0983 * * *$ \\
\hline Total Rainfall (mm) & $0.1302 * * *$ & $0.1419^{* * *}$ & $0.0831 * * *$ & $0.0815 * * *$ & & $3.1034 * * *$ & $3.1868 * * *$ & $0.1018 * * *$ & $0.1451^{* * *}$ \\
\hline Unemployment Rate & $-19.17819^{* * *}$ & & & $-16.5757^{* * *}$ & & & $272 * * *$ & & \\
\hline Units Affected by Smelly Wind & $-94.9227 * * *$ & $-103.580^{* * *}$ & $-94.7159 * * *$ & $-89.5344^{* * *}$ & & $-1755.36^{* * *}$ & $-1775.15^{* * *}$ & $-92.7039 * * *$ & \\
\hline The United States Business Cycle & $0.3519 * * *$ & 0.1548 & $0.39920 * * *$ & $0.3343^{* * *}$ & & $4.955206^{* * *}$ & $14.01284^{* * *}$ & & $0.291221^{* * *}$ \\
\hline The United States Interest Rate & & & $-8.90013 * * *$ & $-4.95727 * * *$ & $-9.3028 * * *$ & $-88.3976^{* * *}$ & $-94.4327 * * *$ & & \\
\hline The Transaction Volume of Stocks Included in & & & & $-0.0000000039 * * *$ & & & $-2.71 \times 10^{7 * * *}$ & & \\
\hline $\begin{array}{l}\text { Heng Seng gndex } \\
\text { Distance From Landfill * Complaints }\end{array}$ & & & & & & & & $0.0245^{* * *}$ & \\
\hline Distance From Landfill ${ }^{*}$ Municipal Solid Waste & & & & & $-0.00506^{* * *}$ & $-0.0150^{* *}$ & $-0.15927^{* * *}$ & & \\
\hline $\begin{array}{l}\text { Municipal Solid Waste * Units Affected by } \\
\text { Smelly Wind }\end{array}$ & & & & & & & & & $-0.05199 * * *$ \\
\hline
\end{tabular}

Table 2 Results from the generated HAC models (*** represents significant at $1 \%$ level, ${ }^{* *}$ represents significant at $5 \%$ level, * represents means significant at $10 \%$ level. The variable M 2 refers to money supply M1 plus near money. Detail explanation of the variables can be found in Appendix A Table A2. 


\subsection{Factors with Unexpected Negative Correlations to Property Price}

It is assumed that the following variables would increase property prices; however, evidence suggests that they in fact decrease property prices. It is hypothesized that extra wealth earned from the stock market helps to build extra income, and in turn boosts home purchases. However, as the Heng Seng Index or transaction volume increases, housing prices decrease. This could be due to the notion that when stock prices rise, more investors are drawn to the stock market as opposed to the housing market. A one-unit increase in car parks causes housing prices to drop from $\$ 95,928$ to $\$ 59,569$, and ppsf decreases by $\$ 1.389658$. It may be that more car parks imply more vehicles polluting the environment.

It is also hypothesized that the rainfall in Tseung Kwan O negatively affects housing prices. A research study conducted by the Hong Kong Polytechnic University showed that during periods of rainfall, complaints about the South East New Territories Landfill surged. Our results show that when the temperature rises by one unit, the housing price rises. This is an interactive term that combines distance from the landfill and the number of complaints. It is assumed that the term negatively affects housing prices. However, the result is positive and $99 \%$ significant. A one-unit increase in the term results in a $\$ 24.528$ increase in property price.

This positive relationship results from the word of mouth effect. When more municipal solid waste is taken to South East New Territories Landfill, complaints from local residents in Tseung Kwan O increase. Nevertheless, the entire property price in the region increases. This means that our hypothesis is rejected, which we speculate may be because more people become aware of the housing estate when there are more complaints. Yet, these complaints do not mean that the entire housing estate experiences the bad odor. With only a limited number of housing units affected by the odors, this gives rise to the "advertisement effect", and complaints about the bad odor raises the housing prices of the unaffected units, thus leading to an overall increase in housing prices.

It is hypothesized that the interaction term Distance from landfill* MSW has a negative relationship with housing prices. When there is a one-unit increase in municipal solid waste, properties situated further away from the landfill face a 5.061 drop in property prices, as well as drops in saleable and gross price $/ \mathrm{ft}^{2}$. This means that our hypothesis can be accepted. Table 3 illustrates the hypotheses and actual results.

Table 3. Hypotheses and actual results (all of the results are significant at the $1 \%$ level).

\begin{tabular}{ccc}
\hline Variables & Hypothesis Result & Actual Result \\
\hline Adjusted Close Heng Seng Index & + & + \\
Gross Area & + & + \\
Saleable Area & + & - \\
The Best Lending Rate & - & - \\
Car Park & + & + \\
Consumer Price Index & - & + \\
Discount Window Base Rate & + & + \\
Distance From Landfill & + & - \\
Distance From Wan Po Road & - & + \\
Distance to Mass Transit Railway & + & - \\
Floor & + & - \\
Hong Kong Business Cycle & - & - \\
Hong Kong Real Interest Rate & - & + \\
Housing Age & - & + \\
Number of Housing Unit & + & + \\
Money Supply (M2) & + & + \\
Mean Degree Celcius & + & - \\
Mean Wind Speed (Km/h) & - & - \\
Municipal Solid Waste & - & \\
\hline
\end{tabular}


Table 3. Cont.

\begin{tabular}{ccc}
\hline Variables & Hypothesis Result & Actual Result \\
\hline New Loan Drawn Amount & + & + \\
Number of New Loan Drawn & + & + \\
Overall Housing Supply & - & - \\
Private Housing Vacancy & - & - \\
Private Housing Supply & - & - \\
Public Housing Supply & - & + \\
Resident Population & - & + \\
Total Rainfall (mm) & + & - \\
Unemployment Rate & $?$ & + \\
Units Affected By Smelly Wind & - & - \\
The United States Business Cycle & $?$ & - \\
The US Real Interest Rate & - & + \\
The Transaction Volume of Stocks Included in Heng Seng Index & + & - \\
Distance From Landfill * Complaints & + & - \\
Distance From Landfill * Municipal Solid Waste & $?$ & \\
Municipal Solid Waste * Units Affected by Wind & $?$ & - \\
\hline Not" indicates the interaction term between the two factors and “? indicates the variables' expected sign
\end{tabular}

Note: “*” indicates the interaction term between the two factors and "?" indicates the variables' expected sign is unknown.

\section{Conclusions}

Firstly, temperature and rainfall do not negatively affect housing prices, as postulated in the government report. Secondly, housing prices rise, even when the amount of municipal solid waste increases. This variable cannot be explained on its own. Indeed, it must also be combined with the interactive term municipal solid waste and multiple units affected by wind direction and speed. This is because the odor problem does not affect most of the housing estates, but does affect those houses directly facing the landfill. This means that municipal solid waste will only partially affect those that directly face the landfill, and only have a minor effect on those that are not facing the landfill. Moreover, the South East New Territories landfill is well managed to reduce the odor concentration. This explains why housing prices are not adversely affected by the landfill. Thirdly, when there are more complaints, the housing prices increase. This can be explained by the following: since there are more complaints, there is more media coverage of the Tseung Kwan O estates; then, people start to become aware of these housing estates, and subsequently realize that not all of the properties are adversely affected by bad odors.

This research provides some valuable implications for urban planning. Whilst most of the urban planners suggest the distance from the landfill that a housing estate should be built, they must also take into consideration wind direction. Such a consideration is also vital for government policymakers. For example, the direction of pollutants or toxic materials blown from factories should be taken into account when said policymakers initiate land use policy, rather than using distance as the sole consideration. Likewise, when discussing the bad odor generated from restaurants, which affects nearby housing, wind direction should be taken into account instead of how far the restaurant is located from the housing. More importantly, this paper provides a new direction in studying the impact of externalities on housing prices. Traditionally, the real estate sector has mainly been concerned with the impact of externalities in accordance to distance. This research suggests that other factors, such as wind direction, may have to be additionally considered.

Finally, and similar to any other research, this study has limitations. For example, one may argue that the adoption of a single case study from Tseung Kwan O means that the research lacks representativeness. However, the strength of this approach is that it accounts for and includes the differences. The experiences of Galileo, Newton, Einstein, Bohr, Darwin, Marx, Freud, and Flyvbjerg hammer home the point that both human and natural sciences can be advanced by a single case [51]. 
Here, we attempt to open the dialogue for further research concerning the externality in other countries, as well as different forms of externality, such as the impact of bad odors from restaurants on housing prices. Indeed, the question must be asked: when most past studies and even policymakers focus primarily on distance, should we include wind direction as well?

Author Contributions: Rita $\mathrm{Yi} \mathrm{Man} \mathrm{Li}$ is responsible for the whole research design and writing. Ching $\mathrm{Yu} \mathrm{Li}$ is responsible for writing the paper.

Conflicts of Interest: The authors declare no conflicts of interest.

\section{Appendix A}

Table A1. Information on Sample Estates.

\begin{tabular}{|c|c|c|c|c|c|}
\hline Sample Estate & $\begin{array}{c}\text { Year of } \\
\text { Completion }\end{array}$ & Housing Statistics & Additional Features & $\begin{array}{l}\text { Transportation } \\
\text { Options }\end{array}$ & $\begin{array}{l}\text { Distance to } \\
\text { Landfill }\end{array}$ \\
\hline Park Central & $\begin{array}{l}2002,2003 \text {, and } \\
2005\end{array}$ & $\begin{array}{l}\text { Phase: } 2 \\
\text { Towers: } 12 \\
\text { Housing units: } 4152 \\
\end{array}$ & $\begin{array}{l}50,000 \mathrm{ft}^{2} \text { shopping mall, } 250,000 \mathrm{ft}^{2} \\
\text { clubhouse with swimming pool, } \\
\text { gym room }\end{array}$ & $\begin{array}{l}\text { Tseung Kwan O } \\
\text { MTR Station } \\
\text { Public bus terminal }\end{array}$ & $\begin{array}{l}3.75 \mathrm{~km} \\
(2.33 \mathrm{mi})\end{array}$ \\
\hline $\begin{array}{l}\text { Tseung Kwan } \\
\text { O Plaza }\end{array}$ & 2003 & $\begin{array}{l}\text { Towers: } 8 \\
\text { Storeys: } 45 \\
\text { Housing units: } 2880 \\
\end{array}$ & $\begin{array}{l}56,000 \mathrm{ft}^{2} \text { shopping mall, wet market, } \\
\text { two clubhouses with swimming pool, } \\
\text { sport facilities, relaxation zone }\end{array}$ & $\begin{array}{l}\text { Tseung Kwan O } \\
\text { MTR Station } \\
\text { Public bus terminal }\end{array}$ & $\begin{array}{l}3.69 \mathrm{~km} \\
(2.29 \mathrm{mi})\end{array}$ \\
\hline $\begin{array}{l}\text { Oscar by the } \\
\text { Sea }\end{array}$ & 2001 & $\begin{array}{l}\text { Towers: } 7 \\
\text { Storeys: } 43 \text { to } 49 \\
\text { Housing units: } 1959 \\
\end{array}$ & $\begin{array}{l}35,000 \mathrm{ft}^{2} \text { clubhouse with swimming } \\
\text { pool, golf course, gym, library, } \\
110,000 \mathrm{ft}^{2} \text { relaxation zone }\end{array}$ & Public bus terminal & $\begin{array}{l}3.37 \mathrm{~km} \\
(2.09 \mathrm{mi})\end{array}$ \\
\hline La Cite Noble & 1999 & $\begin{array}{l}\text { Towers: } 6 \\
\text { Storeys: } 46 \text { to } 49 \\
\text { Housing units: } 2552\end{array}$ & $\begin{array}{l}38,000 \mathrm{ft}^{2} \text { shopping mall, clubhouse, } \\
\text { snooker, music room, gym }\end{array}$ & $\begin{array}{l}\text { Tseung Kwan O } \\
\text { MTR Station } \\
\text { Public bus terminal }\end{array}$ & $\begin{array}{l}4.04 \mathrm{~km} \\
(2.51 \mathrm{mi})\end{array}$ \\
\hline $\begin{array}{l}\text { Bauhinia } \\
\text { Garden }\end{array}$ & 2001 & $\begin{array}{l}\text { Towers: } 8 \\
\text { Storeys: } 40 \\
\text { Housing units: } 3200\end{array}$ & $\begin{array}{l}\text { First SMART housing estate: fibre } \\
\text { optic internet connections, intranet } \\
\text { booking facilities, swimming pool, } \\
\text { basketball court, sports facilities }\end{array}$ & $\begin{array}{l}\text { Tseung Kwan O } \\
\text { MTR Station } \\
\text { Public bus terminal }\end{array}$ & $\begin{array}{l}3.84 \mathrm{~km} \\
(2.39 \mathrm{mi})\end{array}$ \\
\hline LOHAS Park & $\begin{array}{l}\text { Phase 1: } 2008 \\
\text { Phase 2: } 2013 \\
\text { Phase 3: under } \\
\text { construction }\end{array}$ & $\begin{array}{l}\text { Phases: } 3 \\
\text { Towers: } 50 \\
\text { Storeys: Phase 1: } 68 \\
\text { Phase 2: Le Prestige: } 70, \text { Le } \\
\text { Prime: } 76 \text {, Le Splendeur: } 72 \\
\text { Housing units: } 21,500\end{array}$ & $\begin{array}{l}\text { Approximately } 50,000 \mathrm{~m}^{2} \text { of } \\
\text { retail space }\end{array}$ & $\begin{array}{l}\text { LOHAS Park MTR } \\
\text { station } \\
\text { Public bus terminal }\end{array}$ & $\begin{array}{l}2.00 \mathrm{~km} \\
(1.24 \mathrm{mi})\end{array}$ \\
\hline $\begin{array}{l}\text { Residence } \\
\text { Oasis }\end{array}$ & 2005 & $\begin{array}{l}\text { Towers: } 6 \\
\text { Storeys: } 40 \\
\text { Housing units: } 2130\end{array}$ & $\begin{array}{l}\sim 1,800,000 \mathrm{ft}^{2} \text { clubhouse with } \\
\text { facilities such as a swimming pool, } \\
\text { gym, and others } \\
\sim 60,000 \mathrm{ft}^{2} \text { shopping mall, providing } \\
43 \text { shops }\end{array}$ & $\begin{array}{l}\text { Hang Hau MTR } \\
\text { station } \\
\text { Different buses and } \\
\text { minibuses } \\
\text { Link bridges } \\
\end{array}$ & $\begin{array}{l}4.29 \mathrm{~km} \\
(2.67 \mathrm{mi})\end{array}$ \\
\hline The Grandiose & 2006 & $\begin{array}{l}\text { Towers: } 3 \\
\text { Storeys: } 57 \\
\text { Housing units: } 1472\end{array}$ & $\begin{array}{l}120,000 \mathrm{ft}^{2} \text { clubhouse with } \\
\text { various facilities }\end{array}$ & $\begin{array}{l}\text { Tseung Kwan O } \\
\text { MTR station }\end{array}$ & $\begin{array}{l}3.72 \mathrm{~km} \\
(2.31 \mathrm{mi})\end{array}$ \\
\hline Ocean Shores & 2001 to 2003 & $\begin{array}{l}\text { Towers: } 15 \\
\text { Storeys: } 57 \\
\text { Housing units: } 5728\end{array}$ & $\begin{array}{l}\text { A clubhouse with swimming facilities } \\
\text { and other child facilities. } \\
\sim 28,300 \mathrm{ft}^{2} \text { shopping mall, providing } \\
13 \text { shops }\end{array}$ & $\begin{array}{l}\text { A connecting } \\
\text { bridge ( } 5 \text { to } 15 \mathrm{~min}) \\
\text { to MTR stations }\end{array}$ & $\begin{array}{l}3.72 \mathrm{~km} \\
(2.31 \mathrm{mi})\end{array}$ \\
\hline The Wing & 2014 & $\begin{array}{l}\text { Phases: } 2 \\
\text { Towers: } 6 \\
\text { Storeys: } 38 \text { to } 41 \\
\text { Housing units: } 1028\end{array}$ & $\begin{array}{l}\text { A } 5 \text { and a } 3 \text { star hotel, namely } \\
\text { Crowne Plaza Hotel and Holiday Inn } \\
\text { Express, respectively. } \\
\sim 200,000 \mathrm{ft}^{2} \text { shopping mall with over } \\
100 \text { retail stores and restaurants, and } \\
\text { a cinema. } \\
\sim 64,000 \mathrm{ft}^{2} \text { public area }\end{array}$ & $\begin{array}{l}\text { Tseung Kwan O } \\
\text { MTR station }\end{array}$ & $\begin{array}{l}3.59 \mathrm{~km} \\
(2.23 \mathrm{mi})\end{array}$ \\
\hline
\end{tabular}

Table A2. Variables Explanation.

\begin{tabular}{ll}
\hline \multicolumn{1}{c}{ Variables } & \multicolumn{1}{c}{ Rationales and Sources of Data } \\
\hline Gross Area of the Housing Unit (GAHU) & $\begin{array}{l}\text { The Hong Kong Special Adminitration Region (HKSAR) Building Department's Plot Ratio } \\
\text { is used to calculate the Gross Floor Area (GFA). Based on the GFA, the Gross Area of the } \\
\text { Housing Unit is calculated. Despite building regulation 7(2), developers include } \\
\text { recreational spaces, service rooms, and the lobby in the calculation of the Gross Area of the } \\
\text { Housing Unit (Legco.gov.hk, 2000). }\end{array}$ \\
\hline Saleable Area of the Housing Unit (SAHU) & $\begin{array}{l}\text { According to the Residential Property (Firsthand Sales) Ordinance, saleable area implies } \\
\text { the floor area of the residential property, including balconies, utility platforms, verandas, } \\
\text { and other areas that will comprise parts of the residential property. }\end{array}$ \\
\hline Price of the housing unit & $\begin{array}{l}\text { The price of the housing unit is collected from the Midland Housing Property's housing } \\
\text { transaction data. }\end{array}$ \\
\hline
\end{tabular}


Table A2. Cont.

\begin{tabular}{|c|c|}
\hline Variables & Rationales and Sources of Data \\
\hline Floor & $\begin{array}{l}\text { Higher floors have purer air with less odor and pollutants than the lower floors. The } \\
\text { higher floors may also have a higher property price, because the view that can be enjoyed } \\
\text { from these floors is better than that from the lower floors. }\end{array}$ \\
\hline Housing Units and Housing Age & $\begin{array}{l}\text { The total number of housing units built by the provider per tower is collected from the } \\
\text { Building Department, while the housing age is calculated by subtracting the housing } \\
\text { estate's year of completion from 2014. The year of completion is collected from Midland } \\
\text { Housing Property. }\end{array}$ \\
\hline $\begin{array}{l}\text { Car Parks and Distance to Mass Transit Railway } \\
\text { (MTR) }\end{array}$ & $\begin{array}{l}\text { The number of car parks affects residents' convenience and housing prices. This data is } \\
\text { collected from Midland Housing Property. Similarly, a shorter distance between the } \\
\text { housing estate and the Mass Transit Railway increases residents' convenience [52-54]. }\end{array}$ \\
\hline Distance from landfill and Wan Po Road & $\begin{array}{l}\text { According to local residents, the distance from the landfill and Wan Po Road to the } \\
\text { housing estates is inversely proportional to the odor's severity. The distance is measured } \\
\text { by the Google map measurement function. }\end{array}$ \\
\hline $\begin{array}{l}\text { Municipal Solid Waste (MSW) and } \\
\text { Environmental Complaints }\end{array}$ & $\begin{array}{l}\text { As the landfill receives more municipal solid waste, including domestic solid waste, the } \\
\text { odor from the garbage and household refuse will increase, which leads to a decrease in } \\
\text { property prices. Similarly, more environment-related complaints about the South East New } \\
\text { Territories landfill decreases the property prices. The Environmental Protection } \\
\text { Department provided data on municipal solid waste entering the landfill, and on } \\
\text { environmental complaints about the landfill from } 2004 \text { to } 2014 \text {. }\end{array}$ \\
\hline Climatological Data & $\begin{array}{l}\text { A government report has shown that temperature and rainfall are directly proportional to } \\
\text { the odor at Tseung Kwan O. On the other hand, the wind speed dilutes and reduces the } \\
\text { odor. Therefore, temperature (degrees Celsius), rainfall (mm) and wind speed }(\mathrm{km} / \mathrm{h}) \text { data } \\
\text { from 1-1-1999 to 31-12-2014 at the Keung Kwan O regional weather station are collected } \\
\text { from the Hong Kong Observatory. The expectation-maximization algorithm is used to fill } \\
\text { in missing data, if necessary. }\end{array}$ \\
\hline Resident population & $\begin{array}{l}\text { This paper includes both usual residents and mobile residents from the Hong Kong } \\
\text { Census Department's yearly census data. Research shows that the resident population has } \\
\text { a positive relationship with the property prices. }\end{array}$ \\
\hline $\begin{array}{l}\text { Housing Supply (new housing completion and } \\
\text { private housing vacancies) }\end{array}$ & $\begin{array}{l}\text { When housing supply is high, housing prices drop. The new housing completion data } \\
\text { from } 2010 \text { to } 2014 \text { is extracted from the Hong Kong Housing Authority's Housing in } \\
\text { Figures. The number of private housing vacancies per year is extracted from the Rating } \\
\text { and Valuation Department, while the number of public and private housing units per year } \\
\text { is extracted from the Hong Kong Housing Committee's Housing in Figures. The overall } \\
\text { housing is the sum of the public and private housing units. }\end{array}$ \\
\hline New Loans Drawn & $\begin{array}{l}\text { The Hong Kong Monetary Authority's monthly data on new loans drawn shows the } \\
\text { number of new mortgage applications. More mortgages imply a higher demand for } \\
\text { housing and higher property prices. }\end{array}$ \\
\hline Discount Window Base Rate & $\begin{array}{l}\text { The discount window base rate affects the mortgage interest rate, which can again affect } \\
\text { the property price. The current discount window base rate is set at the United States } \\
\text { Federal Funds Target Rate or } 50 \text { basis points above the average of the five-day moving } \\
\text { averages of the overnight and one-month Hong Kong Interbank Offer Rate or, depending } \\
\text { on which is higher. }\end{array}$ \\
\hline $\begin{array}{l}\text { The Transaction Volume of Stocks Included in Hang } \\
\text { Seng Index (HSI) }\end{array}$ & $\begin{array}{l}\text { The Transaction Volume of Stocks Included in the Hang Seng Index is collected from } \\
\text { Yahoo Finance. It is included in this research due to its contemporaneous relationship with } \\
\text { housing prices and stock prices, due to wealth effect. }\end{array}$ \\
\hline Adjusted Closed Hang Seng Index (HSI) & $\begin{array}{l}\text { Studies have shown that the stock market has a long run causality with the property } \\
\text { market [55]. In this study, the Adjusted Closed Hang Seng Index data collected from Yahoo } \\
\text { Finance is used, as it includes dividends and splits, which are more accurate than utilizing } \\
\text { the Opened Hang Seng Index or Closed Hang Seng Index. }\end{array}$ \\
\hline $\begin{array}{l}\text { The United StatesReal Interest Rate and } \\
\text { Business Cycle }\end{array}$ & $\begin{array}{l}\text { Hong Kong is under a linked exchange rate with the United States. Thus, Hong Kong } \\
\text { usually follows the fluctuations of the United States interest rate. Granger causality } \\
\text { relationship between Hong Kong housing prices and the linked exchange rate. } \\
\text { Similarly, the United States business cycle affects the United States dollar currency value, } \\
\text { which affects the Hong Kong property market. The annual United States real interest rate } \\
\text { data and the United States Gross Domestic Product data are extracted from the World } \\
\text { Bank. Cubic spinal interpolation is utilized to convert the annual United States interest rate } \\
\text { into quarterly data, while the Hodrick-Prescott filter is applied on the United States Gross } \\
\text { Domestic Product data to obtain quarterly data. }\end{array}$ \\
\hline Hong Kong Real Interest Rate and HK Business Cycle & $\begin{array}{l}\text { Previous research shows that interest rate affect the demand for home ownership [56], } \\
\text { wWhen the real interest rate rises, the housing demand and the housing prices decrease. } \\
\text { Likewise, the Hong Kong economy also affects housing prices. The Hong Kong real } \\
\text { interest rate is calculated from the United States real interest rate. The Hong Kong business } \\
\text { cycle data is extracted from the World Bank and the Hodrick-Prescott filter is applied to } \\
\text { obtain quarterly data. }\end{array}$ \\
\hline Unemployment rate $(\%)$ & $\begin{array}{l}\text { The Census Department's monthly unemployment rate is included, because a high } \\
\text { unemployment rate leads to fewer people investing in the real estate market, leading to a } \\
\text { decrease in property purchases. }\end{array}$ \\
\hline $\begin{array}{l}\text { Overnight Hong Kong Interbank Offered } \\
\text { Rate (HIBOR) }\end{array}$ & $\begin{array}{l}\text { The overnight Hong Kong Interbank Offered Rate is the rate for the prime bank to pay for } \\
\text { the Hong Kong dollar interbank loans. It has various rates, including overnight, one week, } \\
\text { two weeks, one month, two months, three months, six months, and } 12 \text { months. } \\
\text { However, the overnight Hong Kong Interbank Offered Rate affects the mortgage interest } \\
\text { rate most. The monthly overnight Hong Kong Interbank Offered Rate is extracted from the } \\
\text { Hong Kong Monetary Authority database. }\end{array}$ \\
\hline
\end{tabular}


Table A2. Cont.

\begin{tabular}{ll}
\hline \multicolumn{1}{c}{ Variables } & \multicolumn{1}{c}{ Rationales and Sources of Data } \\
\hline Best Lending Rate (BLR) & $\begin{array}{l}\text { Best Lending Rate represents the interest rate. It is a rate that banks charge to the most } \\
\text { credit-worthy customers. Empirical evidence reflects that money market rates have a close } \\
\text { relationship with the best lending rate [57]. The mortgage payments rise when the best } \\
\text { lending rate rises [57]; then, demand of purchasing property drops, hence property values } \\
\text { fall [58,59]. }\end{array}$ \\
\hline Inflation Rate & $\begin{array}{l}\text { The definition of inflation rate is the continuous growth on the general level of price for } \\
\text { major kinds of goods and services. The Hong Kong Census and Statistics Department has } \\
\text { four series of Consumer Price indices reflecting the four major types of expenditure } \\
\text { consumer price. If the consumption level surges up too fast, people may prefer spending } \\
\text { more, but not on investment in real estate. In this case, the reducing demand on housing } \\
\text { assets dwindles the housing price [60]. }\end{array}$ \\
\hline Money Supply (M2) & $\begin{array}{l}\text { Previous literature shows that money supply affects the property market, and that hot } \\
\text { money inflow, including from China, will also affect the international market, including } \\
\text { the Hong Kong housing market [61-63]. }\end{array}$ \\
\hline Units affected by wind direction & $\begin{array}{l}\text { This indicates the housing units that are affected by odor produced from the landfill. } \\
\text { According to the report from the government, the garbage odor is smelled when the wind } \\
\text { direction is from the southeast. We assume that the odor will follow the wind and blow } \\
\text { towards the units from the landfill. Secondly, when the wind direction is between } 900 \text { and } \\
\text { 1800 (south east wind), we mark them as } 1 \text { or else } 0 \text { as others. In this case, we can select } \\
\text { certain units that face the landfill and always have a southeast wind with garbage odor. } \\
\text { Data of the wind direction is collected from the Hong Kong Observatory Tseung Kwan } O \\
\text { regional weather station. }\end{array}$ \\
\hline New Loan amount & $\begin{array}{l}\text { This measures the amount of money new mortgage loans borrow and is comprised of } \\
\text { monthly data provided by the Hong Kong Monetary Authority. If more mortgages were } \\
\text { produced, the housing market demand is high, which boosts the housing property price. } \\
\text { Previous research indicated that bank lending affects property prices [64]. }\end{array}$ \\
\hline
\end{tabular}

Table A3. Model Summary.

\begin{tabular}{ccccc}
\hline Model Number & R-Squared & Adjusted R-Squared & F-Statistic & Log Likelihood \\
\hline Model 1 & 0.810977 & 0.810909 & $11,979.11$ & $-304,432.8$ \\
Model 2 & 0.765591 & 0.765533 & $13,329.48$ & $-310,143.1$ \\
Model 3 & 0.834503 & 0.834452 & $16,550.13$ & $-280,134.3$ \\
Model 4 & 0.820537 & 0.820479 & $14,268.40$ & $-303,055.7$ \\
Model 5 & 0.779766 & 0.779703 & $12,451.36$ & $-287,170.4$ \\
Model 6 & 0.687407 & 0.687348 & $11,667.94$ & $-436,866.2$ \\
Model 7 & 0.604910 & 0.604798 & 5384.342 & $-428,763.0$ \\
Model 8 & 0.798959 & 0.798867 & 8715.760 & $-190,648.3$ \\
Model 9 & 0.629650 & 0.629545 & 5978.948 & $-299,969.1$ \\
\hline
\end{tabular}


Table A4. Correlation matrix between variables.

\begin{tabular}{|c|c|c|c|c|c|c|c|c|c|c|c|c|c|c|}
\hline Variables & $\begin{array}{c}\text { Gross } \\
\text { Area }\end{array}$ & Car Park & $\begin{array}{c}\text { Discount } \\
\text { Window } \\
\text { Base Rate }\end{array}$ & $\begin{array}{c}\text { WanPo } \\
\text { Raod }\end{array}$ & $\begin{array}{c}\text { Landfil } \\
\text { Distance }\end{array}$ & $\begin{array}{l}\text { Degree } \\
\text { Celsius }\end{array}$ & $\begin{array}{c}\text { Us } \\
\text { Business } \\
\text { Cycle }\end{array}$ & Rainfall & $\begin{array}{l}\text { Resident } \\
\text { Population }\end{array}$ & Floor & $\begin{array}{c}\text { Number of } \\
\text { Housing Unit }\end{array}$ & $\begin{array}{l}\text { Housing } \\
\text { Age }\end{array}$ & $\begin{array}{c}\text { Overall } \\
\text { Housing } \\
\text { Supply }\end{array}$ & Price \\
\hline Gross area & 1 & -0.005 & $-0.179^{* *}$ & -0.146 ** & -0.395 ** & $0.011 *$ & 0.019 ** & 0.039 ** & $0.183^{* *}$ & $0.176^{* *}$ & -0.453 ** & $-0.493 * *$ & 0.236 ** & $0.608 * *$ \\
\hline Car park & -0.005 & 1 & -0.021 ** & 0.608 ** & $0.322 * *$ & -0.005 & $-0.181^{* *}$ & -0.020 ** & $-0.137^{* *}$ & $-0.032^{* *}$ & $0.084 * *$ & $0.118 * *$ & $-0.120^{* *}$ & -0.092 ** \\
\hline Discount Window Baserate & -0.179 ** & -0.021 ** & 1 & $0.168^{* *}$ & 0.171 ** & -0.021 ** & 0.486 ** & -0.048 ** & $-0.659 * *$ & $-0.130 * *$ & $0.338^{* *}$ & 0.421 ** & $-0.862 * *$ & $-0.454 * *$ \\
\hline Wan Po Raod & $-0.146 * *$ & 0.608 ** & $0.168 * *$ & 1 & $0.373 * *$ & $0.009 *$ & -0.031 ** & $-0.047 * *$ & -0.231 ** & $-0.158 * *$ & 0.396 ** & $0.383 * *$ & $-0.250 * *$ & -0.133 ** \\
\hline Landfill Distance & $-0.395 * *$ & $0.322 * *$ & $0.171^{* *}$ & $0.373 * *$ & 1 & $-0.016 * *$ & $-0.185^{* *}$ & $-0.099 * *$ & -0.326 ** & $-0.214^{* *}$ & $0.319 * *$ & $0.715^{* *}$ & -0.330 ** & -0.386 ** \\
\hline Degree Celsius & $0.011 *$ & -0.005 & -0.021 ** & $0.009 *$ & -0.016 ** & 1 & -0.036 ** & 0.080 ** & 0.013 ** & 0.002 & 0.024 ** & -0.004 & $0.088^{* *}$ & 0.006 \\
\hline The United States Business Cycle & $0.019^{* *}$ & $-0.181^{* *}$ & 0.486 ** & -0.031 ** & $-0.185 * *$ & -0.036 ** & 1 & 0.015 ** & 0.045 ** & $0.015^{* *}$ & 0.088 ** & $0.079 * *$ & -0.380 ** & 0.034 ** \\
\hline Rainfall & $0.039 * *$ & -0.020 ** & -0.048 ** & -0.047 ** & -0.099 ** & $0.080^{* *}$ & $0.015^{* *}$ & 1 & $0.069 * *$ & $0.020 * *$ & 0.009 * & $-0.092 * *$ & $0.109 * *$ & 0.067 ** \\
\hline Resident population & 0.183 ** & $-0.137 * *$ & $-0.659 * *$ & $-0.231 * *$ & $-0.326 * *$ & 0.013 ** & $0.045 * *$ & $0.069 * *$ & 1 & $0.126 * *$ & $-0.350 * *$ & $-0.460 * *$ & $0.957 * *$ & $0.650 * *$ \\
\hline Floor & 0.176 ** & $-0.032 * *$ & -0.130 ** & $-0.158 * *$ & $-0.214 * *$ & 0.002 & $0.015 * *$ & 0.020 ** & $0.126 * *$ & 1 & $-0.178 * *$ & $-0.242 * *$ & $0.189 * *$ & 0.223 ** \\
\hline Number of Housing Unit & $-0.453 * *$ & $0.084^{* *}$ & 0.338 ** & 0.396 ** & 0.319 ** & $0.024^{* *}$ & 0.088 ** & $0.009 *$ & -0.350 ** & $-0.178 * *$ & 1 & $0.643 * *$ & -0.332 ** & -0.517 ** \\
\hline Housing Age & -0.493 ** & $0.118^{* *}$ & $0.421 * *$ & $0.383 * *$ & $0.715^{* *}$ & -0.004 & $0.079 * *$ & $-0.092 * *$ & -0.460 ** & -0.242 ** & $0.643^{* *}$ & 1 & $-0.591 * *$ & $-0.572^{* *}$ \\
\hline Overall Housing Supply & 0.236 ** & -0.120 ** & $-0.862 * *$ & $-0.250 * *$ & -0.330 ** & $0.088^{* *}$ & -0.380 ** & 0.109 ** & $0.957^{* *}$ & $0.189 * *$ & $-0.332 * *$ & $-0.591 * *$ & 1 & 0.572 ** \\
\hline Price & $0.608^{* *}$ & $-0.092 * *$ & $-0.454 * *$ & $-0.133 * *$ & $-0.386^{* *}$ & 0.006 & $0.034^{* *}$ & 0.067 ** & 0.650 ** & 0.223 ** & $-0.517 * *$ & -0.572 ** & $0.572 * *$ & 1 \\
\hline
\end{tabular}

Note: "**** Significant at 99\% level, “**" significant at 95\% level and "** significant at 90\% level. 


\section{References}

1. Environmental Protection Department. Available online: http://www.epd.gov.hk/epd/english/top.html (accessed on 7 January 2018).

2. Jaillon, L.; Poon, C.S.; Chiang, Y.H. Quantifying the waste reduction potential of using prefabrication in building construction in Hong Kong. Waste Manag. 2009, 29, 309-320. [CrossRef] [PubMed]

3. EDMS Consulting Limited. Provision of Services for Odour Study in Tseung Kwan O Area. Available online: http:/ / www.districtcouncils.gov.hk/sk/tc_chi/links/files/Executive\%20Summary\%20of\%20the\% 20Odour\%20Study\%20in\%20Tseung\%20Kwan\%200\%20Area.pdf (accessed on 7 January 2018).

4. Geng, B.; Bao, H.; Liang, Y. A study of the effect of a high-speed rail station on spatial variations in housing price based on the hedonic model. Habitat Int. 2015, 49, 333-339. [CrossRef]

5. Andersson, D.E.; Shyr, O.F.; Fu, J. Does high-speed rail accessibility influence residential property prices? Hedonic estimates from Southern Taiwan. J. Transp. Geogr. 2010, 18, 166-174. [CrossRef]

6. Kiel, K.A.; Williams, M. The impact of superfund sites on local property values: Are all sites the same? J. Urban Econ. 2007, 61, 170-192. [CrossRef]

7. Funke, M.; Paetz, M. Housing prices and the business cycle: An empirical application to Hong Kong. J. Hous. Econ. 2013, 22, 62-76. [CrossRef]

8. Shi, S.; Jou, J.-B.; Tripe, D. Can interest rates really control house prices? Effectiveness and implications for macroprudential policy. J. Bank. Financ. 2014, 47, 15-28. [CrossRef]

9. Bai, C.; Li, Q.; Ouyang, M. Property taxes and home prices: A tale of two cities. J. Econ. 2014, 180, 1-15. [CrossRef]

10. Ohno, S.; Shimizu, J. Do exchange rate arrangements and capital controls influence international capital flows and housing prices in Asia? J. Asian Econ. 2015, 39, 1-18. [CrossRef]

11. Giudice, V.D.; De Paola, P.; Manganelli, B.; Forte, F. The monetary valuation of environmental externalities through the analysis of real estate prices. Sustainability 2017, 9, 229. [CrossRef]

12. Hanushek, E.; Yilmaz, K. Household location and schools in metropolitan areas with heterogeneous suburbs: Tiebout, Alonso, and government policy. J. Public Econ. Theory 2013, 15, 829-855.

13. Hanushek, E.; Yilmaz, K. The complementarity of Tiebout and Alonso. J. Hous. Econ. 2007, 16, $243-261$. [CrossRef]

14. Grislain-Letrémy, C.; Katossky, A. The impact of hazardous industrial facilities on housing prices: A comparison of parametric and semiparametric hedonic price models. Reg. Sci. Urban Econ. 2014, 49, 93-107. [CrossRef]

15. Cho, S.-H.; Roberts, R.K.; Kim, S.G. Negative externalities on property values resulting from water impairment: The case of the Pigeon River Watershed. Ecol. Econ. 2011, 70, 2390-2399. [CrossRef]

16. Del Giudice, V.; De Paola, P. The effects of noise pollution produced by road traffic of Naples Beltway on residential real estate values. Appl. Mech. Mater. 2014, 587-589, 2176-2182. [CrossRef]

17. Brandt, S.; Maennig, W. Road noise exposure and residential property prices: Evidence from Hamburg. Transp. Res. Part D Transp. Environ. 2011, 16, 23-30. [CrossRef]

18. Stetler, K.M.; Venn, T.J.; Calkin, D.E. The effects of wildfire and environmental amenities on property values in northwest Montana, USA. Ecol. Econ. 2010, 69, 2233-2243. [CrossRef]

19. Jim, C.; Chen, W.Y. Impacts of urban environmental elements on residential housing prices in Guangzhou (China). Landsc. Urban Plan. 2006, 78, 422-434. [CrossRef]

20. Dekkers, J.E.; van der Straaten, J.W. Monetary valuation of aircraft noise: A hedonic analysis around Amsterdam airport. Ecol. Econ. 2009, 68, 2850-2858. [CrossRef]

21. Phillips, K.; Longhurst, P.; Wagland, S. Assessing the perception and reality of arguments against thermal waste treatment plants in terms of property prices. Waste Manag. 2014, 34, 219-225. [CrossRef] [PubMed]

22. Farber, S. Undesirable facilities and property values: A summary of empirical studies. Ecol. Econ. 1998, 24, 1-14. [CrossRef]

23. Baker, B. Perception of hazardous waste disposal facilities and residential real property values. Impact Assess. 1988, 6, 47-54. [CrossRef]

24. Bleich, D.H.; Findlay, M.; Phillips, G.M. An evaluation of the impact of a well-designed landfill on surrounding property values. Apprais. J. 1991, 59, 247-252. 
25. Owusu, G.; Nketiah-Amponsah, E.; Codjoe, S.N.A.; Afutu-Kotey, R.L. How do Ghana's landfills affect residential property values? A case study of two sites in Accra. Urban Geogr. 2014, 35, 1140-1155. [CrossRef]

26. Du Preez, M.; Lottering, T. Determining the negative effect on house values of proximity to a landfill site by means of an application of the hedonic pricing method: The environment. S. Afr. J. Econ. Manag. Sci. (Suid-Afrik. Tydskr. Ekonom. Bestuurswet.) 2009, 12, 256-262. [CrossRef]

27. Seok Lim, J.; Missios, P. Does size really matter? Landfill scale impacts on property values. Appl. Econ. Lett. 2007, 14, 719-723. [CrossRef]

28. Ketkar, K. Hazardous waste sites and property values in the state of New Jersey. Appl. Econ. 1992, 24, 647-659. [CrossRef]

29. Kinnaman, T.C. A landfill closure and housing values. Contemp. Econ. Policy 2009, 27, 380-389. [CrossRef]

30. Lynch, C. Big data: How do your data grow? Nature 2008, 455, 28-29. [CrossRef] [PubMed]

31. Athey, S. Beyond prediction: Using big data for policy problems. Science 2017, 355, 483-485. [CrossRef] [PubMed]

32. Andrea, D.M.; Marco, G.; Michele, G. A formal definition of big data based on its essential features. Libr. Rev. 2016, 65, 122-135.

33. Neeta, B. Knowledge Integration Strategies for Entrepreneurship and Sustainability; IGI Global: Hershey, PA, USA, 2018; pp. 1-413.

34. Li, R.Y.M.; Chau, K.W. Econometric Analyses of International Housing Markets; Routledge: Oxon, UK, 2016.

35. Lavee, D.; Bahar, S. Estimation of external effects from the quarrying sector using the hedonic pricing method. Land Use Policy 2017, 69, 541-549. [CrossRef]

36. Walsh, P.; Mui, P. Contaminated sites and information in hedonic models: An analysis of a NJ property disclosure law. Resour. Energy Econ. 2017, 50, 1-14. [CrossRef]

37. Li, M.M.; Brown, H.J. Micro-neighborhood externalities and hedonic housing prices. Land Econ. 1980, 56, 125-141. [CrossRef]

38. Rivas Casado, M.; Serafini, J.; Glen, J.; Angus, A. Monetising the impacts of waste incinerators sited on brownfield land using the hedonic pricing method. Waste Manag. 2017, 61, 608-616. [CrossRef] [PubMed]

39. Zeileis, A. Econometric Computing with HC and HAC Covariance Matrix Estimators; Wirtschaftsuniversität Wien: Wien, Austria, 2004.

40. Al-Zoubi, H.; Maghyereh, A. Stationary component in stock prices: A reappraisal of empirical findings. Multinatl. Financ. J. 2007, 11, 287-322. [CrossRef]

41. Kim, M.S.; Sun, Y. Spatial heteroskedasticity and autocorrelation consistent estimation of covariance matrix. J. Econ. 2011, 160, 349-371. [CrossRef]

42. Dempster, A.P.; Laird, N.M.; Rubin, D.B. Maximum likelihood from incomplete data via the EM algorithm. J. R. Stat. Soc. Ser. B (Methodol.) 1977, 39, 1-38.

43. Miljkovic, T.; Barabanov, N. Modeling veterans' health benefit grants using the expectation maximization algorithm. J. Appl. Stat. 2015, 42, 1166-1182. [CrossRef]

44. Do, C.B.; Batzoglou, S. What is the expectation maximization algorithm? Nat. Biotechnol. 2008, 26, 897-899. [CrossRef] [PubMed]

45. Tzoreff, E.; Weiss, A.J. Expectation-maximization algorithm for direct position determination. Signal Process. 2017, 133, 32-39. [CrossRef]

46. Dadashkarimi, J.; Shakery, A.; Faili, H.; Zamani, H. An expectation-maximization algorithm for query translation based on pseudo-relevant documents. Inf. Process. Manag. 2017, 53, 371-387. [CrossRef]

47. Fort, H.; Mungan, M. Using expectation maximization and resource overlap techniques to classify species according to their niche similarities in mutualistic networks. Entropy 2015, 17, 7680-7697. [CrossRef]

48. Gao, S.; Zhang, Z.; Cao, C. On a generalization of cubic spline interpolation. J. Softw. 2011, 6, $1632-1639$. [CrossRef]

49. Kim, T.-W.; Kvasov, B. A shape-preserving approximation by weighted cubic splines. J. Comput. Appl. Math. 2012, 236, 4383-4397. [CrossRef]

50. Abbas, M.; Majid, A.A.; Ali, J.M. Positivity-preserving rational bi-cubic spline interpolation for 3D positive data. Appl. Math. Comput. 2014, 234, 460-476. [CrossRef]

51. Merriam, S.B. Qualitative Research: A Guide to Design and Implementation; John Wiley \& Sons: Hoboken, NJ, USA, 2009. 
52. Seo, K.; Golub, A.; Kuby, M. Combined impacts of highways and light rail transit on residential property values: A spatial hedonic price model for Phoenix, Arizona. J. Transp. Geogr. 2014, 41, 53-62. [CrossRef]

53. Diaz, R.B.; Mclean, V.A. Impacts of Rail Transit on Property Values; Booz Allen \& Hamilton Inc.: Mclean, VA, USA, 2006.

54. Debrezion, G.; Pels, E.; Rietveld, P. The impact of rail transport on real estate prices: An expirical analysis of the Dutch housing market. Urban Stud. 2010, 48, 997-1015. [CrossRef]

55. Quan, D.C.; Titman, S. Do real estate prices and stock prices move together? An international analysis. Real Estate Econ. 1999, 27, 183-207. [CrossRef]

56. Li, R.Y.M. Generation X and Y's Demand for Homeownership in Hong Kong. Pac. Rim Real Estate J. 2015, 21, 15-36. [CrossRef]

57. Goodhart, C.; Hofmann, B. Do asset prices help to predict consumer price inflation? Manch. Sch. 2000, 68, 122-140. [CrossRef]

58. Burdekin, R.C.K.; Tao, R. Chinese real estate market performance. Chin. Econ. 2014, 47, 5-26. [CrossRef]

59. Taylor, J.B. The Financial Crisis and the Policy Responses: An Empirical Analysis of What Went Wrong; National Bureau of Economic Research: Cambridge, MA, USA, 2009.

60. Piazzesi, M.; Schneider, M. Inflation and the Price of Real Assets; Federal Reserve Bank of Minneapolis: Minneapolis, MN, USA, 2012.

61. Favilukis, J.; Kohn, D.; Ludvigson, S.C.; Van Nieuwerburgh, S. International capital flows and house prices: Theory and evidence. In Housing and the Financial Crisis; University of Chicago Press: Chicago, IL, USA, 2012; pp. 235-299.

62. Tsuyuguchi, Y. The Recent Flow of "Hot Money" in China; Center for Monetary Cooperation in Asia Bank of Japan: Tokyo, Japan, 2009.

63. Tillmann, P. Capital inflow shocks and house prices: Aggregate and regional evidence from Korea. J. East Asian Econ. Integr. 2013, 17, 129-159.

64. Liang, Q.; Cao, H. Property prices and bank lending in China. J. Asian Econ. 2007, 18, 63-75. [CrossRef]

(C) 2018 by the authors. Licensee MDPI, Basel, Switzerland. This article is an open access article distributed under the terms and conditions of the Creative Commons Attribution (CC BY) license (http:/ / creativecommons.org/licenses/by/4.0/). 